\title{
COMMUNICATION \\ CLIMATE, COMFORT, \\ AND COLD CALLING
}

AN ANALYSIS OF DISCUSSION-BASED COURSES

AT MULTIPLE UNIVERSITIES

Tasha J. Souza, Humboldt State University

Elise J. Dallimore, Northeastern University

Eric Aoki, Colorado State University

Brian C. Pilling, South Jordan, Utah

One of the challenges in discussion facilitation is creating a climate that allows multiple voices to be heard. Although the practice of calling on students whose hands are not raised has been used to engage the entire class in discussions, many believe that cold calling sabotages the communication climate and makes students extremely uncomfortable. This study examines the impact of cold calling on student comfort and communication climate. The results suggest that when instructors choose to coldcall, they must create a supportive communication climate to ensure student comfort. This study challenges the assumption that cold calling makes students uncomfortable.

\footnotetext{
We would like to thank the reviewers and editors of TIA for their conscientious attention. A special thanks to our mentor and friend Don Wulff, who gave us insightful feedback prior to his untimely passing. This manuscript received the Top Paper Award from the Communication and Instruction Division at the Western States Communication Association convention in Seattle, Washington, in February 2007.
} 
Discussion teaching is a highly effective method to cultivate learning, engage students, and create a positive classroom climate (Brookfield \& Preskill, 1999; Christensen, 1991; Dallimore, Hertenstein, \& Platt, 2005). It is "a systematic way of constructing a context for learning from the knowledge and experience of students" (Elmore, 1991, p. xiv). It offers pedagogical advantages when the objectives are developing critical thinking, cooperation, sensitivity, and discovery (Christensen, 1991). In addition, it enhances classroom cohesion more than lecture as well as students' sense of acceptance and belonging (Anderson \& Nussbaum, 1990). Because discussion can improve students' ability to evaluate the logic of positions that they and others hold (Anderson \& Nussbaum, 1990), it develops students' self-awareness and appreciation of diverse perspectives (Brookfield \& Preskill, 1999). By fostering "an attitude that all ideas are tentative and are offered for examination" (Leonard, 1991, p. 142) and giving responsibility to the students, it generates an atmosphere of mutual trust and respect.

For decades, instructors and scholars have researched the topic of discussion to identify its strongest uses, and strategies to enhance its effectiveness (Christensen, Garvin, \& Sweet, 1991; Christensen \& Hansen, 1987). Of the various strategies, "cold calling" has recently captured attention. Dallimore et al. (2005) define the practice as "any instance in which a teacher calls on a student whose hand is not raised" (p. 23). Many instructors assume that cold calling causes severe student discomfort and may therefore create a defensive communication climate. However, Dallimore, Hertenstein, and Platt (2006) found that it can actually enhance student comfort, as well as increase preparation for class and perceived student learning. Students have identified cold calling as a method for enhancing quality participation and discussion effectiveness (Dallimore, Hertenstein, \& Platt, 2004). However, research has yet to examine its effect on communication climate. If the practice increases student comfort, it may also help create a positive communication climate. This study examines the impact of cold calling on student comfort and communication climate in discussion-based courses among different student populations and in several types of educational institution.

\section{The Literature on Communication Climate and Cold Calling}

One of the challenges in discussion facilitation is creating a communication climate that encourages and allows multiple voices to be heard. Communication climate consists of the negotiated characteristics of the 
communication context that influence and are influenced by subsequent communication events (Souza, 1999). Because communication is a process, behaviors of "individuals involved in interactions affect each other and eventually serve to create a characteristic communication climate" (Darling \& Civikly, 1987, p. 25). The relationship between communication and communication climate is recursive in that communication constructs the communication climate and the communication climate affects communication (Souza, 1999).

If students do not equally participate, the value of discussion is limited, especially for students less inclined to volunteer (Brookfield \& Preskill, 1999). Excluding the investigations on cold calling by Dallimore et al. $(2004,2005,2006,2008)$, research examining the effectiveness of strategies to increase student participation during discussion is limited. Fishman (1997) suggests that techniques such as study questions and response logs enhance student participation in classroom discussion. Scollon and Bau (1981) suggest that clearly stated instructor expectations are useful in increasing student participation. Other strategies include requiring students to speak a specific number of times by using poker chips or comment cards for tracking (Davis, 1993), assigning roles in discussions to students (Smith \& Smith, 1994), and using online discussions (Arbaugh, 2000; Bump, 1990).

Rosmarin (1987) discusses the experience of students being assigned on short notice to lead each class session's discussion with an analysis of an assigned case. Similarly, Rhodes and Schaible (1992) and Robinson and Schaible (1993) advocate student-led discussion in which the discussion leader is randomly chosen at the beginning of each class. Some specific strategies include asking all students to prepare questions prior to class about their reading, which they may then be asked to share (Frederick, 1987), or soliciting nonvoluntary participation to begin case discussion by calling on students "without previous warning" (Hansen, 1987, p. 134). Dallimore et al. (2004, 2005, 2006) specifically investigate the practice of cold calling to encourage student participation in discussion. Their research (Dallimore et al., 2006) suggests that cold calling (in one discussion-based classroom) increases participation frequency, is associated with increased student preparation, and leads to increased comfort. Other studies indicate that (1) students report that both required (i.e., cold calling) and graded participation increase participation quality and discussion effectiveness (Dallimore et al., 2004), and (2) cold calling leads to increased oral and written communication skill development (Dallimore et al., 2008).

Despite the potential benefits from cold calling, instructors may resist using the practice, contending that cold calling comes at the expense of 
student comfort (Dallimore et al., 2005). With the notable exception of Dallimore et al. (2006), little investigation of student comfort during discussions has been done. One factor that can have tremendous impact on student comfort is the communication climate.

\section{The Literature on Communication Climate}

An examination of the communication climate focuses on the critical role of interaction in creating and sustaining the climate. Communication climate is often compared metaphorically to the weather (Pace $\&$ Faules, 1994). A warm climate invites open communication and a cool climate promotes closed or defensive communication. A communication climate is omnipresent and continuously influences people's behaviors and perceptions. As Pace and Faules (1994) state, "a particular communication climate provides guidelines for individual decisions and behavior" (p. 105). However, communication climate is not simply external to individuals; just as people influence weather through deforestation, pollution, depletion of the ozone layer and so on, people's actions, values, and beliefs influence the communication climate (Souza, 1999).

Patel (1970) determined the communication climate using dimensions such as freedom and restriction, and Gibb (1961) included supportiveness and defensiveness. The products of an eight-year study of group interaction, Gibb's dimensions presents six continuums of behaviors that characterize defensive and supportive climates: superiority versus equality, evaluation versus description, neutrality versus empathy, strategy versus spontaneity, control versus a problem orientation, and certainty versus provisionalism. Gibb suggests that people in defensive climates defend themselves and make it difficult to "convey ideas clearly" (p. 148). In this type of climate, communication is characterized by a high level of ambiguity, distortion, and ineffective listening. In contrast, a supportive communication climate has clear messages, few distortions, and effective listening. Gibb contends that communication is more efficient in supportive climates than defensive ones.

Communication climate researchers frequently apply Gibb's framework to analyze the communication climate in a variety of contexts. For example, Rozema (1986) applied it to adolescent communication and suggested that a defensive communication climate hinders sex education in the home. Although Gibb's framework has been highly influential and widely cited, his dimensions emerged in an organizational context and have seen little use in classroom research.

Yet communication plays a primary role in creating a supportive learning environment and establishing relationships (Pierce, 1994). Thus the 
communication climate can create or disintegrate effective interpersonal relationships between student and instructor and influence learning. For example, Trickett and Moos (1973) found that positive student-teacher interactions resulted in greater course satisfaction and higher student achievement. In addition, research shows that a poor communication climate increases resistance to learning (Rosenfeld, 1983) and reduces commitment to course outcomes (Hill \& Northouse, 1978). Conversely, students in supportive communication climates retain significantly more knowledge than those in defensive climates (Hays, 1970).

Because communication climate relates to student learning, retention, relationships, course satisfaction, and achievement, it may also affect students' comfort in classrooms with cold calling. We know a positive climate enhances trust (Gibson \& Cohen, 2003), which would seem a necessary ingredient for student comfort with cold calling.

Because research suggests that students are fearful of asking questions (Dillon, 1981; Ortiz, 1988), instructors may assume that students are also fearful of nonvoluntarily answering questions. However, Dallimore et al. (2006) reported that cold calling does not undermine student comfort because it increases student preparation. Might communication climate also play a role in student comfort?

\section{Methodology}

Exploratory research suggests that the use of cold calling leads to multiple positive outcomes. However, research has yet to specifically investigate the impact of cold calling in multiple discussion-based courses. Thus, this research represents a study investigating the use of cold calling in multiple classroom contexts. We were particularly interested in the effect of such environments on student comfort and communication climate.

\section{Research Questions}

Many instructors fear that cold calling will make their students uncomfortable. So we asked this first research question: How does the use of cold calling affect student comfort? Additionally, because communication climate influences student comfort students may be less apt to participate, and less likely to learn, in a communication climate perceived as defensive. It stands to reason that a major concern of instructors about cold calling is its potentially detrimental effects on the communication climate. Thus we pose the second research question: How does cold calling affect the students' perceptions of the communication climate? 


\section{Research Design}

This study was a pre-/postsurvey control group design. Four instructors administered the same pre- and postsurvey instrument in nine courses. Six of these courses were experimental groups and enrolled 130 students. Three were control groups and enrolled 62 students. Pedagogical practices were the same across all the instructors involved, except for the use of cold calling in the experimental group classes.

\section{The Instructors, Courses, and Institutions}

The research was conducted in nine undergraduate communication courses, both upper and lower division, taught by four instructors (the authors) at four educational institutions. Two of the instructors are male and two are female; three are Euro-American and one is Asian/Mexican American. The courses investigated included four public speaking courses, two gender and communication courses, and one each of cocultural communication, consultation skills, and interpersonal communication courses. The institutions were diverse geographically and institutionally (public and private, rural and urban, small liberal arts to large comprehensive to land grant research). Their student populations varied from economically diverse to largely upper-middle-class and from ethnically diverse to largely homogeneous.

The instructors collaborated to maintain pedagogical consistency across courses. All the courses in the study were primarily discussionbased, with some student presentations, small groups, case studies, and lecture. All of the courses graded participation, ranging from 10 percent to 22 percent of the total grade. In the experimental groups $(N=6)$, the instructors explained the choice, rationale, and advantages of cold calling, although they did not refer to the practice as "cold calling"; nor did they inform the students that this practice was being assessed. Because student experience with cold calling varied, the instructors agreed they would call on a student by name before asking questions and would ask questions from across all levels of Bloom's taxonomy (1956). They also agreed to maintain a supportive communication climate in their classes.

\section{Sample}

Of the total number of students enrolled in these courses, 192 completed and returned both pre- and postsurveys and were included in the analysis. To ensure the surveys were anonymous, we used a PIN to pair pre- and 
postsurvey questionnaires for analysis. (The survey form is available from the first author on request.)

\section{Data}

All data are student self-reported measures. We administered the presurvey on the first day of class, before explaining the class structure or participation requirements, and administered the postsurvey during the final week of classes. The presurvey established a baseline of the students' attitudes and behaviors regarding class participation and discussion teaching. The postsurvey questionnaire focused on their views on, comfort with, and behavior during the discussion teaching in the course. Students had about twenty minutes to complete the latter questionnaire after being informed that it was part of a research project on the effectiveness of class discussions as a learning tool. To avoid biasing responses, we did not mention cold call or classroom climate in the questionnaire. In the postsurvey, however, we did ask students if calling on them when their hands weren't raised had an impact on their participation.

The pre- and postsurvey questions (see Tables 13.1 and 13.2) were part of a more extensive questionnaire that asked students to report their level of participation, preparation, and learning in the course relative to others they had taken. The form contained both open-ended questions and close-ended items scored on a seven-point Likert scale. Although all responses were anonymous, we took extra effort to obtain candid responses by assuring students that we would not review the questionnaires until after we submitted final grades.

\section{Data Analysis}

In addition to descriptive statistical analysis of the pre- and postsurvey questionnaire data, we conducted a paired sample $t$ test to assess relationships between pre-and postsurvey variables in the control and experimental groups. To analyze the qualitative data, we took a detailed, line-by-line approach, which Strauss and Corbin (1990) characterized as the most detailed and generative type of analysis. We segmented and coded the discourse into thematic "thought" units. We gave one sentence two or three codes if it contained more than one main idea and two or three sentences a single code if the main idea did not change. Our thematic analysis included searching for and developing individual themes, determining theme significance, and grouping relative to others (similar to those used by Peterson et al., 1994). 
By noting the emergent themes and patterns (Miles \& Huberman, 1994 ) and clustering data into fourteen themes, we created four broad communication climate categories. A second rater coded the data, and the reliability of these categories was determined by computing a coefficient of agreement. Between coders, Cohen's Kappa intercoder reliability score was 96.8 percent as based on independent coding of 100 percent of the qualitative data.

\section{Results}

The results are summarized here as they address the two research questions: How does the use of cold calling affect student comfort? How does cold calling affect the students' perceptions of the communication climate?

\section{Student Comfort and Cold Calling During Discussion}

According to the presurvey, respondents moderately enjoyed (5.57) classes in which instructors use discussion, with the control group (5.25) reporting significantly less enjoyment than those in the experimental group $(5.72)(t(190)=2.22, \mathrm{p}<.05$; see Table 13.1). Respondents reported experiencing some enjoyment (4.82) participating in discussion generally; those in the control group (4.47) reported significantly less enjoyment than those who would be exposed to cold calling (4.88) $(t(198)=2.04, \mathrm{p}<.05)$. Both groups were somewhat comfortable (4.55) participating in discussions generally, with the control group significantly more comfortable than the experimental group. When class participation was graded, respondents were not very comfortable (3.78), with those in the control group significantly less comfortable than the experimental group. Finally, respondents reported that discussion participation in general was a little easier (3.77) than difficult, with the control group reporting significantly more difficulty with discussion participation than the experimental group.

Results from the postsurvey, shown in Table 13.1, indicate that respondents experienced a moderately high level of comfort (5.83) with discussion participation in these specific classes and experienced a moderately higher level of comfort (5.32) in these specific classes as compared to others. No significant differences in comfort were found between groups. However, we did discover a difference in ease during discussions between groups. Those in the control group reported significantly more ease with discussion participation than those in the experimental group, even 


\section{Table 13.1. Survey Results: Class Discussion and Enjoyment, Comfort, and Ease}

\begin{tabular}{|c|c|c|c|c|c|}
\hline \multirow[b]{2}{*}{ Item } & \multirow[b]{2}{*}{ Total } & \multirow[b]{2}{*}{ Control } & \multirow[b]{2}{*}{ Exp. } & \multicolumn{2}{|c|}{ Anchor Points } \\
\hline & & & & $1=$ & $7=$ \\
\hline \multicolumn{6}{|c|}{ Results for Presurvey Questions } \\
\hline $\begin{array}{l}\text { Enjoyment in partici- } \\
\text { pating in discussion }\end{array}$ & 4.82 & 4.47 & $4.98^{*}$ & Not at all & Very much \\
\hline $\begin{array}{l}\text { Enjoyment in classes } \\
\text { with discussion }\end{array}$ & 5.57 & 5.25 & $5.72^{*}$ & Not at all & Very much \\
\hline $\begin{array}{l}\text { Comfort with class } \\
\text { discussion }\end{array}$ & 4.55 & 4.15 & $3.59^{*}$ & Uncomfortable & Comfortable \\
\hline $\begin{array}{l}\text { Comfort in classes } \\
\text { with graded } \\
\text { discussion }\end{array}$ & 3.78 & 3.44 & $3.93^{*}$ & Less comfort & $\begin{array}{l}\text { More } \\
\text { comfort }\end{array}$ \\
\hline $\begin{array}{l}\text { Level of ease in } \\
\text { participating } \\
\text { in discussion }\end{array}$ & 3.77 & 4.15 & $3.59^{*}$ & Easy & Very difficult \\
\hline \multicolumn{6}{|c|}{ Results for Postsurvey Questions } \\
\hline $\begin{array}{l}\text { Comfort participat- } \\
\text { ing in this class }\end{array}$ & 5.83 & 5.92 & 5.79 & Uncomfortable & Comfortable \\
\hline $\begin{array}{l}\text { Comfort participat- } \\
\text { ing in this class ver- } \\
\text { sus others }\end{array}$ & 5.32 & 5.52 & 5.23 & Less comfort & $\begin{array}{l}\text { More } \\
\text { comfort }\end{array}$ \\
\hline $\begin{array}{l}\text { Ease of participating } \\
\text { in this class }\end{array}$ & 3.23 & 2.83 & $3.42^{*}$ & Easy & Very difficult \\
\hline \multicolumn{6}{|l|}{ Presurvey Questions } \\
\hline \multicolumn{6}{|c|}{$\begin{array}{l}\text { Enjoyment } \\
\text { - How much do you enjoy participating in class discussion? } \\
\text { - How much do you enjoy class when instructors use discussion in their } \\
\text { teaching? }\end{array}$} \\
\hline \multicolumn{6}{|c|}{$\begin{array}{l}\text { Comfort } \\
\text { - When participation in class discussions is graded, how does this affect your } \\
\text { comfort in the course? } \\
\text { In general, when I participate in class discussions, I feel: (uncomfortable, } \\
\text { comfortable) }\end{array}$} \\
\hline \multicolumn{6}{|c|}{$\begin{array}{l}\text { Ease } \\
\text { - In general, I find participation in class discussion to be: (easy, difficult) }\end{array}$} \\
\hline $\begin{array}{l}\text { "Indicates significant } \\
\text { and experimental gr } \\
\text { samples. }\end{array}$ & 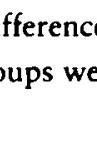 & es $(p<.0$ & W & individual means & $\begin{array}{l}\text { for control } \\
\text { ependent }\end{array}$ \\
\hline
\end{tabular}


though the control group began the semester reporting less ease than the experimental group.

Results from a paired-samples $t$ test (see Table 13.2) reveal that respondents felt much more comfortable participating in the classes evaluated for this study (5.83) than they felt about participating in class discussions in general (4.55). Table 13.2 also reports that respondents felt more ease participating in the specific classes in this study (3.23) than about discussion participation in general (3.75). We also used paired-samples $t$ tests to assess differences in level of ease in discussion participation within the two groups (experimental and control). We found no significant differ-

\section{Table 13.2. Postsurvey Results: Class Discussion and Comfort/Ease Comparison}

Anchor Points

\begin{tabular}{|c|c|c|c|c|}
\hline Item & In General & In This Class & $1=$ & $7=$ \\
\hline $\begin{array}{l}\text { Comfort } \\
\text { participating } \\
\text { in discussion }\end{array}$ & 4.55 & $5.83^{*}$ & Uncomfortable & Comfortable \\
\hline Control group & 4.34 & $5.92^{*}$ & Uncomfortable & Comfortable \\
\hline $\begin{array}{l}\text { Experimental } \\
\text { group }\end{array}$ & 4.64 & $5.79^{*}$ & Uncomfortable & Comfortable \\
\hline $\begin{array}{l}\text { Ease in } \\
\text { participating } \\
\text { in discussion }\end{array}$ & 3.75 & $3.23^{*}$ & Easy & Very difficult \\
\hline Control group & 4.15 & $2.83^{*}$ & Easy & Very difficult \\
\hline $\begin{array}{l}\text { Experimental } \\
\text { group }\end{array}$ & 3.56 & $3.42^{*}$ & Easy & Very difficult \\
\hline
\end{tabular}

\section{Postsurvey Questions}

Comfort

- In this class, when I participated in class discussions, I felt: (uncomfortable, comfortable)

- Compared to other courses, when I participated in class discussions in this course, I felt: (uncomfortable, comfortable)

- If you felt more comfortable participating in this course than in other courses, why was that true?

- If you felt less comfortable participating in this course than in other courses, why was that true?

Ease

- In this class, I found class discussions to be: (easy, very difficult)

*Indicates significant differences $(p<.05)$ when means were compared through a paired-sample $t$ test. 
ences in the experimental group, suggesting respondents felt similarly about the ease with which they could participate in discussion generally (3.56) and the ease with which they actually participated in the classes used for data collection (3.42). However, we did identify a significant difference in the control group, indicating that these respondents felt discussion participation in general (4.15) was significantly more difficult than participating in the classes used for this study (2.83).

Eighty-five percent of the experimental group and 87 percent of the control group reported being more comfortable in the course under investigation than in other courses. Therefore, only 15 percent of respondents in the experimental groups ( $N=20$ of 130 ) felt less comfortable in the cold-calling courses than in others; 12 percent of control group respondents ( $N=7$ of 62 ) felt less comfortable in control classes. When asked why they were more or less comfortable, respondents cited communication climate characteristics, though they were not specifically asked about them in the survey. The themes related to communication climate are described in the following section. However, responses not referencing communication climate related largely to three themes: the teacher, the nature of the course, and student preparation and comprehension.

Although no respondents mentioned the instructor as a reason for being less comfortable, twenty-one stated that they were more comfortable in the given class than in others because of the instructor. They explained that instructors helped them feel comfortable by being flexible and creating an encouraging, supportive, and respectful environment. For example, one experimental group respondent described being more comfortable "[b]ecause the [instructor] was willing to change things to make students more comfortable." A control group respondent noted, "The teacher created an environment that leaves everyone feeling comfortable in their own opinion. There is no judgment presented by the teacher on wrong and right opinions."

Twenty respondents stated that the nature of the course content was the reason for more or less comfort in the given class. Fourteen respondents who were more comfortable in the given course than in others stated it was because it was a "speech" or a "communication" course. Other respondents mentioned course design as affecting their comfort. For example, a respondent suggested, "This class was designed for participation in class discussion." The six respondents less comfortable in the given class claimed it was due to the difficulty of the course content or design. One respondent claimed, "I felt less comfortable because the concepts were very challenging." Another maintained, "The subject matter was sometimes really difficult to discuss." 
Student preparation and comprehension were mentioned by fourteen respondents. Six claimed they were more comfortable because they were better prepared. To illustrate, one respondent wrote, "I got used to talking in this course because I was prepared so l'd know what I was talking about." Although no one attributed less comfort to poor preparation, four respondents blamed their comprehension level. As one stated, "When I felt uncomfortable, it was not that I was unprepared, but that I didn't fully comprehend the subject matter." Conversely, four respondents felt more comfortable as a result of their solid comprehension.

\section{Impact of Cold Calling on Communication Climate}

We identified fourteen themes identified from the data related to communication climate and grouped them into four categories: (1) climate of confirmation, (2) climate of engagement, (3) climate of familiarity, and (4) climate of freedom (listed in order of frequency from most to least). When asked why they were less comfortable in the given class, respondents gave reasons related to two of four communication climate themes.

Climate of confirmation. Forty-two respondents alluded to a communication climate of confirmation as the reason they were more comfortable. In a communication climate of confirmation, the negotiated characteristics of the communication context recognize another person's worth (Cissna \& Seiburg, 1995). We distilled four indicators of this type of climate: accepting communication, nonjudgmental communication, personal communication, and respectful communication. For instance, one respondent reported, "The atmosphere was very open and I felt I could express my opinion without being judged" (experimental group respondent: coded nonjudgmental). Here are further examples of each indicator (comments came from respondents in courses from all four instructors):

\section{Exhibit 13.1. Student Comfort: Climate of Confirmation}

$\mathrm{N}=42,69 \%$ experimental, $31 \%$ control

Accepting

- "I felt like my contributions were valued and discussed. I could get my questions answered." (Experimental group respondent)

- "I felt that my opinion was important." (Control group respondent)

Nonjudgmental

- "It was expected that everyone would participate and therefore I felt less scrutinized by peers." (Experimental group respondent) 


\section{Exhibit 13.1. (Continued)}

- "The teacher created an environment that leaves everyone feeling comfortable in their own opinion. There is no judgment presented by the teacher on wrong and right opinions." (Control group respondent)

Personal

- "The people were just connected, it was comfortable getting to know everyone." (Experimental group respondent)

Respectful

- "The instructor set a tone that made you want to respect others." (Experimental group respondent)

In fact, the most common theme among the more comfortable respondents was a climate of confirmation, and the most common theme among the less comfortable ones was a climate of disconfirmation. Nine of the twenty-five less comfortable respondents described a communication climate of disconfirmation, with characteristics such as judgment, intimidation, and lack of acceptance. As one experimental group respondent claimed, "There are a lot of opinionated people in this class that [sic] I feel judge others." Another remarked, "I felt that some people didn't like what I had to say because of my background."

Climate of engagement. Thirty-three respondents gave communication climate of engagement as the reason for being more comfortable. This type of climate is one in which the negotiated characteristics of the communication context promote involvement and engagement. We identified

\section{Exhibit 13.2. Student Comfort: Climate of Engagement}

$\mathrm{N}=33,82 \%$ experimental, $18 \%$ control

Expectation of engagement or participation

- "[I felt more comfortable] because everyone was expected to and did participate rather than a few select people." (Experimental group respondent)

Equal student involvement

- "Because I felt that a lot of people participated in this class, so it made it more comfortable to speak up as well." (Experimental group respondent)

- "Other students were participating also, so I felt more comfortable participating myself." (Control group respondent)

Personal engagement

- “As I started participating more, I felt more confident." (Experimental group respondent) 
three themes related to a climate of engagement: expectation of engagement or participation, equal student involvement (participation), and personal engagement (individual participation). Exhibit 13.2 offers examples of each indicator. Comments came from respondents in courses from all four instructors. Less comfortable respondents did not mention engagement or lack of it in the given course.

Climate of freedom. Twenty-six respondents cited a communication climate of freedom as the reason for their greater comfort. In this kind of climate, the negotiated characteristics of the communication context are not confined to restrictive rules; nor do they seem to be under the control or power of another person or persons. We found three indicators of a communication climate of freedom: open communication, unrestricted communication, and discussion-based communication. We consider these to be indicators because they offer students the freedom to communicate about various topics in various ways. Exhibit 13.3 offers examples of each indicator. Comments came from students in courses from all four instructors. Four respondents, however, felt less comfortable in the given class. One experimental group respondent asserted, "I didn't like feeling forced to talk for 25 percent of my grade; too much pressure." No one gave cold calling, which might be seen as controlling, as a reason for discomfort.

Climate of familiarity. Fifteen respondents attributed their greater comfort to a communication climate of familiarity-that is, one in which the negotiated characteristics of the communication context are known and familiar. Respondents claimed that knowing their fellow students, the instructor, and the environment enhanced their comfort. Comments came from students in courses from all four instructors (see Exhibit 13.4 for sample comments). Neither familiarity nor the lack of it was mentioned by less comfortable respondents.

\section{Exhibit 13.3. Student Comfort: Climate of Freedom}

$\mathrm{N}=26,61 \%$ experimental, $39 \%$ control

Open communication

"The class was a much more open and friendly environment, therefore it was easier to give input." (Experimental group respondent)

Unrestricted communication

"I just wanted to be heard and get my opinion out there and maybe introduce a different view for others to consider." (Control group respondent)

Discussion-based communication

"I felt like the atmosphere was more open to discussion and the class was set up to participate in easily." (Control group respondent) 


\section{Discussion}

We set out to examine the practice of cold calling more precisely by exploring its relationship to comfort and climate. This study is the first to relate communication climate to cold calling and examine the effects of cold calling in multiple classrooms at multiple institutions.

\section{Comfort May Not Decrease with Cold Calling}

Our results present a strong argument against the common belief that cold calling decreases student comfort in the discussion classroom. Similar significant differences were found in the results for both the experimental and control groups when those groups were analyzed through two separate paired-samples $t$ tests, indicating that factors other than cold calling increased their comfort participating in discussions. The experimental group results-with respect to increasing student comfort-are especially relevant because an increase in student comfort with discussion runs counter to common beliefs regarding the effects of cold calling.

The presurvey data provided an interesting baseline assessment. Although the experimental group liked discussions generally, neither group enjoyed participating in them. However, both groups asserted some level of comfort with discussion participation. The control group began the semester reporting significantly more comfort than the experimental group. However, the control group reported significantly less comfort than the experimental group when such participation was graded. This finding suggests respondents are moderately comfortable speaking in class but less so when their contributions are graded.

Although levels of enjoyment and comfort differed, and both groups claimed a moderate level of comfort during discussion generally, the postsurveys revealed that both groups reported a moderately high level of comfort with discussion in these specific classes. Regardless of coldcalling use, both groups' comfort increased, and there were no significant differences found in comfort level. Further, both groups reported much more comfort participating in the classes evaluated than participating in other classes. Finally, not one respondent mentioned cold calling as a

\section{Exhibit 13.4. Student Comfort: Climate of Familiarity}

\section{$\mathrm{N}=15,73 \%$ experimental, $27 \%$ control}

- "I felt more comfortable in this class because ... I got to know and trust my classmates." (Experimental group respondent)

- "Got to know the people in my class and I was comfortable with them." (Control group respondent) 
reason for their discomfort. These results suggest that comfort is neither decreased nor increased by cold calling (at least not among these students and instructors). Rather the increase in student comfort was related to other classroom variables.

\section{Cold Calling Can Make Discussions More Difficult for Students}

Although both groups experienced increased comfort, they differed in their reported level of ease with discussion participation. They both reported that discussion participation was somewhat easier than difficult in these specific classes, but the control group reported significantly more ease with discussion participation than those in the experimental group. It makes sense that students would find a discussion with cold calling more difficult, given the need to prepare and respond to questions nonvoluntarily. But despite this finding, both were equally comfortable. Student comfort is an important element of a supportive communication climate-and therefore critical to effective discussion-but we suggest that difficulty (as opposed to "ease") of discussion participation can be desirable. Discussion strategies that raise difficulty can challenge students positively, both intellectually and communicatively, because they usually give students more practice in constructing, articulating, defending, and critiquing arguments.

\section{Student Participation, Not Preparation, Is More Important for Student Comfort}

Eighty-six percent of the students in both groups claimed more comfort in the course under study than in other courses. When asked why, they referred to the communication climate, the teacher, the nature of the course, and student preparation and comprehension, in order of frequency. Previous research by Dallimore et al. (2006) suggests that "when students are well prepared, they may be more comfortable participating, and the more they participate, the more comfortable they may become with it" (p. 18). Only five respondents from the experimental group claimed increased preparation was the reason for their greater comfort. Respondents did, however, claim that their (and their peers') increased participation was a significant reason for greater comfort.

\section{Communication Climate Is the Most Important Factor for Student Comfort}

What is clear from this research is the importance of communication climate for student comfort in discussion-based classrooms. An overwhelming majority of students ( 78 percent) who reported increased comfort described 
some aspect of communication climate as the reason they were more comfortable; 48 percent of those reporting less comfort relative to other courses identified communication climate as a factor. The difference in percentages suggests (1) elements of a supportive communication climate had the greatest influence on increased student comfort (relative to other factors reported), and (2) elements of a defensive communication climate were rarely cited as a reason for decreased comfort, with more than 52 percent attributing to other factors such as course content and their lack of comprehension. Both the experimental and control groups reported that they were more comfortable because the communication climate was confirming, engaged, free, and familiar.

This study confirms the importance of a communication climate that recognizes another's worth, similar to "empathy" as suggested by Gibb (1961). Our unique contributions to the communication climate research are the characteristics of engagement, freedom, and familiarity. From this study, we deem such qualities, which are not present in Gibb's framework, as central to classroom interaction. Regardless of the use of cold calling, students are comfortable during discussion when all students are engaged, have the freedom to express a variety of viewpoints, and are familiar with the instructor, the students, and the environment. Counter to widespread suspicions, the experimental group did not perceive the communication climate as restrictive in the classroom with cold calling.

\section{Cold Calling Can Increase Overall Student Engagement}

Qualitative responses from the experimental (two-thirds) and control groups (one-third) were consistent with the overall N. Roughly one-third of the responses for each of the climate categories came from respondents in the control group, with one notable exception. Of the comments on a climate of engagement, 82 percent were from the experimental group. Although we expected both groups to participate, more respondents commented on student engagement in the cold-calling classroom. This finding suggests greater engagement in classes with cold calling.

\section{Practical Applications and Pedagogical Implications}

From these findings, we see four major pedagogical implications for the practice of cold calling. Instructors should consider several facets of classroom climate, including some not in Gibb's framework (1961). 


\section{Create a Climate of Confirmation in the Classroom}

Students must anticipate they will not be ridiculed or shamed before they take the risk of participating. Before speaking up comfortably either voluntarily or nonvoluntarily, they need to feel they will be affirmed and valued as individuals. Similar to Gibb's climate characteristics (1961) of empathy and equality, the communication climate of confirmation is accepting and nonjudgmental. We maintain that effective communication should be a relationship-building process rather than merely a means for transferring information and ideas (Robertson, 2002). Instructors must recognize the importance of affirming students before considering cold calling, because students could easily see it as punitive or threatening in a climate of disconfirmation.

\section{Create a Climate of Engagement}

Students are comfortable during discussions when participation is expected, when all students are engaged and personally contribute, and cold calling makes this happen. Now that several studies demonstrate that the practice need not sacrifice student comfort, instructors can feel confident in using it and other strategies to increase student engagement, such as grading participation and using multiple active-learning strategies.

\section{Create a Climate of Freedom}

The climate of freedom is similar to Gibb's (1961) notion of "spontaneity," which refers to messages that are open, honest, and free from ulterior motives. Respondents described this climate as characterized by openness, lack of confining rules, and an emphasis on discussion. These distinctions are appropriate for the classroom context. Students feel more comfortable participating when no rules restrict how to communicate and what to say. They described the allowance of multiple opinions and humor in a relaxed environment as the key to their comfort. Having a climate of freedom creates opportunities for them to "share the teaching task with one another and their instructor" (Christensen, 1991, p. 99). This freedom encourages students to share power over and responsibility for the learning experience of the class (Christensen, 1991).

\section{Create a Climate of Familiarity in the Classroom}

Individuals feel more comfortable with self-disclosure or speaking in public when the audience and setting are known. Students too feel more comfortable participating in discussion when familiar with the instructor, 
other students, and class setting. This familiarity develops through interaction. Its value extends the literature on the importance of establishing clear and explicit expectations for students (Davis, 1993).

\section{Limitations of the Study and Future Research}

Our contributions must be understood alongside the limitations of our research. First, although our sample is impressive at the individual level (192 surveys, with nearly sixteen hundred words in our text database), it included nine classes and four instructors at the classroom level. The fact that all four instructors work diligently to create and maintain a supportive communication climate and have been recognized for effective teaching likely affected the results. Future research should examine a variety of instructors with differing styles to further investigate student comfort and positive communication climate in the discussion-based classroom. Although this study suggests what does work when using nonvoluntary participation, it is equally important to know what does not work as well.

This study was based on students' anonymous self-reports. However, some variables, such as frequency of student contributions, grades, and attendance, could be measured directly though observation, video recording, and course outcome data. We would welcome extensions of our research that capture the complexity of the classroom context by using ethnographic approaches and student interviews. Future research also should examine the generalizability of the conclusions, perhaps to graduate students or to courses in other disciplines.

Although we worked to be consistent in the manner and frequency of our use of cold calling, the question remains: Did we cold-call in precisely the same manner? Another important next step in cold-calling research is to turn the lens on the instructor to assess the nature of the cold call and address the effects of various types of cold calls.

In addition, the specific behaviors and characteristics of the instructor and students merit investigation. What role does teacher immediacy play in perceptions of cold calling? Do the student perceptions and expectations of instructors vary according to instructor characteristics, such as ethnicity, sex, gender, and social class? How do student characteristics affect their reactions to cold calling? What does the use of cold calling say to students about power in the classroom? What impact do cold calling and communication climate have on student confidence about participation, participation quality and quantity, and learning? 
Despite these limitations, our research has several implications for practice. When instructors use discussion as a pedagogical tool, they must consider the communication climate. When they choose to cold-call, they must create a supportive communication climate. Students must feel valued, respected, and not judged; they must be engaged personally and as a group during discussions and must feel that communication is open and unrestricted. Further, students must feel a sense of familiarity with the environment, instructor, and other students. In addition to underscoring the need for a supportive communication climate, our research challenges the assumption that cold calling makes students uncomfortable. Can it? Of course. But when the instructor is thoughtful about creating a supportive communication climate, cold calling can serve to engage a wider range of students and incorporate greater diversity of perspective in the discussion.

\section{REFERENCES}

Anderson, J., \& Nussbaum, J. (1990). Interaction skill in instruction settings. In J. A. Daly, G. W. Friedrich, \& A. L. Vangelisti (Eds.), Teaching communication: Theory, research, and methods (pp. 301-316). Hillsdale, NJ: Erlbaum.

Arbaugh, J. B. (2000). The virtual classroom versus physical classroom: An exploratory study of class discussion patterns and student learning in an asynchronous internet-based MBA course. Journal of Management Education, 24(2), 213-233.

Bloom, B. S. (1956). Taxonomy of educational objectives: The classification of educational goals, by a committee of college and university examiners. Handbook 1: Cognitive domain. New York: Longman.

Brookfield, S., \& Preskill, S. (1999). Discussion as a way of teaching: Tools and techniques for democratic classrooms. San Francisco: Jossey-Bass.

Bump, J. (1990). Radical changes in class discussion using networked computers. Computers and the Humanities, 24(1-2), 49-65.

Christensen, C. R. (1991). Every student teaches and every teacher learns: The reciprocal gift of discussion teaching. In C. R. Christensen, D. A. Garvin, \& A. Sweet (Eds.), Education for judgment: The artistry of discussion leadership (pp. 137-152). Boston: Harvard Business School Press.

Christensen, C. R., Garvin, D. A., \& Sweet, A. (Eds.). (1991). Education for judgment: The artistry of discussion leadership. Boston: Harvard Business School Press.

Christensen, C. R., \& Hansen, A. J. (Eds.). (1987). Teaching and the case method: Text, cases, and readings. Boston: Harvard Business School Press. 
Cissna, K. N., \& Seiburg, E. (1995). Patterns of interactional confirmation and disconfirmation. In J. Stewart (Ed.), Bridges not walls: $A$ book about interpersonal communication (6th ed., pp. 292-301). New York: McGraw-Hill.

Dallimore, E. J., Hertenstein, J. H., \& Platt, M. B. (2004). Quality participation and discussion effectiveness: Student generated strategies. Communication Education, 53(1), 103-115.

Dallimore, E. J., Hertenstein, J. H., \& Platt, M. B. (2005). Faculty-generated strategies for "cold-calling" use: A comparative analysis with student recommendations. Journal on Excellence in College Teaching, 16(1), 23-62.

Dallimore, E. J., Hertenstein, J. H., \& Platt, M. B. (2006). Nonvoluntary class participation in graduate discussion courses: Effects of grading and coldcalling. Journal of Management Education, 30(2), 354-377.

Dallimore, E. J., Hertenstein, J. H., \& Platt, M. B. (2008). Using discussion pedagogy to enhance oral and written communication skills. College Teaching, 56(3), 163-172.

Darling, A. L., \& Civikly, J. M. (1987). The effect of teacher humor on student perceptions of classroom communicative climate. Journal of Classroom Interaction, 22(1), 24-30.

Davis, B. G. (1993). Tools for teaching. San Francisco: Jossey-Bass.

Dillon, J. T. (1981). Duration of response to teacher questions and statements. Contemporary Educational Psychology, 6(1), 1-11.

Elmore, R. F. (1991). Foreword. In C. R. Christensen, D. A. Garvin, \& A. Sweet (Eds.), Education for judgment: The artistry of discussion leadership (pp. ix-xix). Boston: Harvard Business School Press.

Fishman, S. M. (1997). Student writing in philosophy: A sketch of five techniques. In M. D. Sorcinelli \& P. Elbow (Eds.), New directions for teaching and learning: No. 69. Writing to learn: Strategies for assigning and responding to uriting (pp. 53-66). San Francisco: Jossey-Bass.

Frederick, P. (1987). The dreaded discussion: Ten ways to start. In C. R. Christensen \& A. J. Hansen (Eds.), Teaching and the case method: Text, cases, and readings (pp. 211-216). Boston: Harvard Business School Press.

Gibb, J. (1961). Defensive communication. Journal of Communication, 11, 332-337.

Gibson, C. B., \& Cohen, S. G. (2003). Virtual teams that work: Creating conditions for virtual collaboration effectiveness. San Francisco: Jossey-Bass.

Hansen, D. J. (1987). Background information on a graduate school of business administration. In C. R. Christensen \& A. J. Hansen (Eds.), Teaching and the case method: Text, cases, and readings (pp. 133-134). Boston:

Harvard Business School Press. 
Hays, E. R. (1970). An ego-threatening classroom communication: A factor analysis of student perceptions. Speech Teacher, 19(1), 43-48.

Hill, S. K., \& Northouse, P. G. (1978). A research design for studying communication climate within an organization. Journal of Business Communication, 15(2), 37-44.

Leonard, H. B. (1991). With open ears: Listening and the art of discussion teaching. In C. R. Christensen, D. A. Garvin, \& A. Sweet (Eds.), Education for judgment: The artistry of discussion leadership (pp. 137-152). Boston: Harvard Business School Press.

Miles, M. B., \& Huberman, A. M. (1994). Qualitative data analysis. Thousand Oaks, CA: Sage.

Ortiz, J. (1988, March). Creating conditions for student questions. Paper presented at the National Seminar on Successful College Teaching, Orlando, FL.

Pace, R. W., \& Faules, D. F. (1994). Organizational communication (3rd ed.). Englewood Cliffs, NJ: Prentice Hall.

Patel, I. J. (1970). Communication in the classroom. Baroda, India: Centre of Advanced Study in Education.

Peterson, T. R., Witte, K., Enkerlin-Hoeflich, E., Espericueta, L., Flora, J. T., Florey, N., et al. (1994). Using informant directed interviews to discover risk orientation: How formative evaluations based in interpretive analysis can improve persuasive safety campaigns. Journal of Applied Communication, 22(3), 199-215.

Pierce, C. (1994). Importance of classroom climate for at-risk learners. Journal of Educational Research, 88(1), 37-42.

Rhodes, G., \& Schaible, R. (1992). Talking students/listening teachers: The student-led discussion. Issues and Inquiry in College Learning and Teaching, 16, 44-61.

Robertson, E. (2002). Using leadership to improve communication climate model: A strategy for engaging leaders in organizational communication. London: Melcrum.

Robinson, B. D., \& Schaible, R. (1993). Women and men teaching “Men, Women, and Work." Teaching Sociology, 21(4), 363-370.

Rosenfeld, L. B. (1983). Communication climate and coping mechanisms in the college classroom. Communication Education, 32(2), 167-174.

Rosmarin, A. (1987). The art of leading a discussion. In C. R. Christensen \& A. J. Hansen (Eds.), Teaching and the case method: Text, cases, and readings (pp. 235-240). Boston: Harvard Business School Press.

Rozema, H. J. (1986). Defensive communication climate as a barrier to sex education in the home. Family Relations, 35(4), 531-537. 
Scollon, S., \& Bau, K. (1981, April). Professional development seminar: A model for making higher education more culturally sensitive. Paper presented at the Conference of the National Association for Asian and Pacific American Education, Honolulu, HI.

Smith, L. J., \& Smith, D. L. (1994, April). The discussion process: A simulation. Journal of Reading, 37(7), 582-584.

Souza, T. J. (1999, November). The social construction of communication climate: An analysis of at-risk students in an alternative high school. Paper presented at the National Communication Association Convention, Chicago.

Strauss, A. L., \& Corbin, J. (1990). Basics of qualitative research. London: Sage.

Trickett, E. J., \& Moos, R. H. (1973). Social environment of junior high and high school classrooms. Journal of Educational Psychology, 65(1), 93-102. 